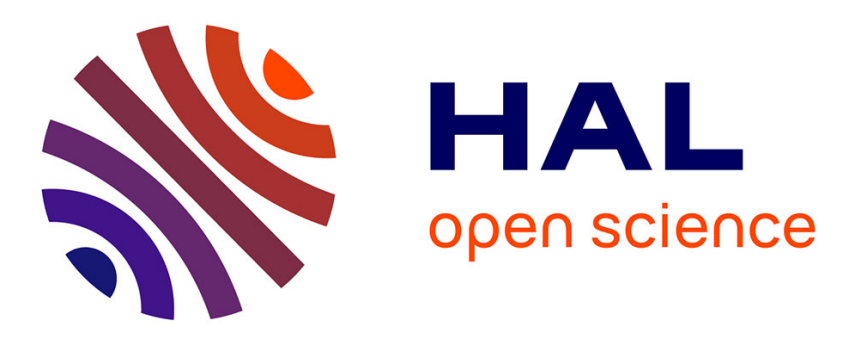

\title{
Selenium controls sex-specific immune response and selenoprotein expression during the acute phase response in mice
}

Mette Stoedter, Kostja Renko, Antonia Hoeg, Lutz Schomburg

\section{- To cite this version:}

Mette Stoedter, Kostja Renko, Antonia Hoeg, Lutz Schomburg. Selenium controls sex-specific immune response and selenoprotein expression during the acute phase response in mice. Biochemical Journal, 2010, 429 (1), pp.43-51. 10.1042/BJ20091868 . hal-00491630

\section{HAL Id: hal-00491630 \\ https://hal.science/hal-00491630}

Submitted on 14 Jun 2010

HAL is a multi-disciplinary open access archive for the deposit and dissemination of scientific research documents, whether they are published or not. The documents may come from teaching and research institutions in France or abroad, or from public or private research centers.
L'archive ouverte pluridisciplinaire HAL, est destinée au dépôt et à la diffusion de documents scientifiques de niveau recherche, publiés ou non, émanant des établissements d'enseignement et de recherche français ou étrangers, des laboratoires publics ou privés. 


\title{
Selenium controls sex-specific immune response and selenoprotein expression during the acute phase response in mice
}

\author{
Mette Stoedter*, Kostja Renko*, Antonia Hög and Lutz Schomburg \\ Institute for Experimental Endocrinology, Charité - Universitätsmedizin Berlin, Südring 10, D-13353 \\ Berlin, Germany.
}

Keywords: trace element, LPS, translation, critical illness, sexual dimorphism short title: Sex-specific selenoprotein regulation in acute phase

*equal contribution

Correspondence should be addressed to

Dr. Lutz Schomburg,

Institute for Experimental Endocrinology,

Charité - Universitätsmedizin Berlin, Südring 10,

D - 13353 Berlin, Germany.

phone: +49-30-450 524289, fax: +49-30-450 524922

E-mail: lutz.schomburg@charite.de.

\begin{abstract}
Abbreviations: ERAD, ER-associated protein degradation; GPX, glutathione peroxidase (human); Gpx, glutathione peroxidase (mouse); LPS, lipopolysaccharide (endotoxin); Se, selenium; SEPP, selenoprotein P (human); SepP, selenoprotein P (mouse); SEPS, selenoprotein S (human); SepS, selenoprotein $\mathrm{S}$ (mouse); TxnRd, thioredoxin reductase.
\end{abstract}

\begin{abstract}
Selenium modifies inflammatory reactions in rodents and humans. The liver controls metabolism and transport of selenium via hepatically-derived selenoprotein P (SEPP). Intracellular selenoprotein S (SEPS) modifies endoplasmic reticulum function and immune cell activity. Polymorphisms in SEPS were associated with cytokine levels and inflammatory diseases in a subset of clinical studies. We hypothesized that sex and selenium represent decisive parameters controlling immune response and regulation of SEPS expression in vivo. Male and female mice on Se-poor diet were supplemented or not with selenite for three days and injected with saline or LPS $24 \mathrm{~h}$ before analysis. Selenium supplementation mitigated the LPS-induced rise in circulating cytokines in male mice. Serum SepP and selenium concentrations decreased in response to LPS whereas hepatic SepS was specifically upregulated despite declining Se concentrations in liver. Hepatic SepS induction was mainly controlled by posttranscriptional mechanisms and attributed to hepatocytes by analysing transgenic mice. Notably, selenium supplementation was essential for an optimal SepS induction. We conclude that selenoprotein biosynthesis becomes redirected in hepatocytes during the acute phase response at the expense of dispensable selenoproteins (e.g. SepP) and in favour of SepS expression thereby causing declining serum selenium and improving liver function. Selenium status and sex control SepS expression and modify cytokine response patterns in serum which might explain contradictory results on associations of SEPS genotype and inflammatory diseases in clinical studies.

\section{INTRODUCTION}

Selenium (Se) is an essential trace element needed for the biosynthesis of a small number of mammalian selenoproteins [1]. Se intake and personal Se status are implicated in wide-spread human pathologies including cancer, cardiovascular disease or neurodegeneration [2]. Recent research has specifically highlighted the importance of Se status for the activity of the immune system [3-5]. Positive effects of Se supplementation have been observed in a number of clinical trials with patients suffering from sepsis [6], human immunodeficiency virus infection [7] or autoimmune thyroid disease
\end{abstract}


[8]. The effects of Se are mediated by selenoproteins, a notion which is supported by association studies linking specific selenoprotein genotypes to human diseases [9, 10]. To assess an individual's Se status, glutathione peroxidase activity in blood cells (GPX1) or plasma (GPX3) and total Se or circulating selenoprotein P (SEPP) concentrations are measured, respectively [11]. SEPP is mainly derived from liver and seems to represent the best Se marker for it accounts for the majority of circulating Se in blood and responds over a broad range to Se intake [12]. Serum Se is an established negative acute phase reactant and declining serum Se levels correlate to low circulating SEPP in sepsis $[13,14]$. Most importantly, the lower the Se status during critical illness the more likely the patients will not survive [6,15-17]. Some but not all clinical trials have proven effective to improve outcome of critically ill patients by Se supplementation but the best application regimen, most suitable Se compound and the mechanisms of action are a matter of discussion [18-20].

One possible molecular component linking Se status with the immune system was recently identified when single nucleotide polymorphisms in the human gene encoding selenoprotein $\mathrm{S}(S E P S)$ were correlated to serum concentrations of proinflammatory cytokines, e.g., IL-6, IL-1 $\beta$ and TNF- $\alpha$ [21]. $S E P S$ encodes an essential factor for retrotranslocation of misfolded proteins from the endoplasmic reticulum (ER) into the cytosol for proteasomal degradation (ERAD, ER-associated protein degradation) $[22,23]$. Hereby, SEPS is connected to a number of physiological pathways that modulate inflammation, e.g., NFKB and JNK activation and induction of acute-phase proteins [24]. Insufficient Se supply might cause impaired SEPS expression leading to reduced ERAD activity and cell dysfunction upon ER stress. Accordingly, proinflammatory cytokines, glucose deprivation or chemically induced ER stress induce SEPS gene expression in vitro [25-27]. A molecular circuit can be envisaged in which inflammatory stimuli induce SEPS biosynthesis as a positive acute phase reactant to ensure efficient ERAD activity, stress relaxation and prevention of apoptosis [26]. We wondered about hepatic SEPS regulation in vivo during the acute phase response since the hepatic Se status and hepatic enzymes involved in selenoprotein biosynthesis are reduced under these conditions [28]. Moreover, we wanted to test the suitability of a short-term Se supplementation strategy as a preventive measure to positively affect the cytokine response pattern and increase selenoprotein expression in order to prepare an individual for an impending sepsis thread. This scenario can be envisaged for a regular patient in the clinics in face of e.g. a surgical intervention [29]. To this end, we have analysed the endotoxin (LPS)-based murine model of septic shock and studied both male and female mice for their regulation of selenoprotein expression differs between the sexes [30]. Our findings indicate mitigating effects of Se supplementation on the LPS-dependent rise of certain cytokines in blood especially in male mice. This response is paralleled by specific changes in selenoprotein expression in hepatocytes in favour of improved ER function during the acute phase and at the expense of SepP production. We conclude that availability of Se is of prime importance for hepatic SepS expression in vivo. This connection might help to explain some of the discrepant findings on the given or missing associations of SEPS genotype with inflammatory diseases in recent clinical studies for these analyses failed to correct for the actual Se status of the probands.

\section{EXPERIMENTAL}

\section{Materials}

All chemicals were of analytical grade and obtained from Sigma (München, Germany). Oligonucleotides were from Invitrogen, restriction endonucleases were from New England Biolabs (Frankfurt, Germany) and Taq polymerase was from Qiagen (Hilden, Germany).

\section{Animal experimentation}

Wild-type C57BL/6J mice were obtained from Charles River (Sulzfeld, Germany) and were bred on regular lab chow (Altromin, Lage, Germany). A time-course analysis of selenoprotein expression after a single injection of LPS was conducted as described before [28]. In addition, transgenic mice on C57BL/6 background carrying a removable gene for the selenocysteine-specific tRNA (floxed Trsp) have been generously supplied by D.L. Hatfield et al. [31] and were bred, genotyped and studied as described [32]. In these mice, selenoprotein expression can become specifically impaired in hepatocytes by crossing these mice with a strain expressing Cre recombinase under an albumin- 
promoter $(\mathrm{Alb}-\mathrm{Cre})$ [33]. In a third experiment, groups of male and female mice ( $\mathrm{n}=6$ per group) were transferred at the age of 45 days (P45) to a Se-poor diet (C1045, Altromin) containing $0.1 \mathrm{ppm}$ Se on average. Then, they received either regular tab water or $100 \mu \mathrm{M} \mathrm{Na}_{2} \mathrm{SeO}_{3}$ in tab water for three days. $24 \mathrm{~h}$ before analysis, all of these mice were injected intraperitoneally once with sterile saline or $100 \mu \mathrm{g}$ LPS per animal (E. coli 55:B5, Sigma) as shown in Fig. 2. Necroscopy, tissue homogenization, RNAisolation, Northern and Western blot analyses were performed as described [28]. The experimental animals received humane care in compliance with the "Guide for the Care and Use of Laboratory Animals" prepared by the National Academy of Sciences, and experiments had been approved by the local governmental authorities in Berlin, Germany.

\section{Enyzme assays}

Hepatic Gpx and thioredoxin reductase (TxnRd) activities were determined as described [30, 34]. Briefly, livers were homogenized on ice in $250 \mathrm{mM}$ sucrose, $20 \mathrm{mM}$ HEPES, and $1 \mathrm{mM}$ EDTA, pH 7.4 and cleared by centrifugation. Protein concentrations were determined in the supernatants by a modified Bradford assay using IgG as standard (Bio-Rad, Muenchen, Germany). NADPH consumption by GSH reductase was recorded at $340 \mathrm{~nm}$ as a measure of oxidized GSH formation in the Gpx reaction with t-butylhydroperoxide as substrate [30]. TxnRd activity was determined by monitoring the NADPH-dependent reduction of 5,5'-dithiobis-(2-nitrobenzoic acid, DTNB) determined as the increase in absorbance at $412 \mathrm{~nm}$ as described [34].

\section{Determination of circulating cytokines}

Aliquots of serum $(10 \mu \mathrm{l} /$ sample) were analyzed by a multiplex analyzer system (Luminex 200, Luminex Corp., Austin, TX) in combination with LINCOplex cytokine immunoassays (Linco Research, St. Charles, MO) as described [30]. The tests for murine Il-6, Mcp1 and TNF- $\alpha$ were conducted according to the manufacturer's instructions and calibration curves were generated with seven commercial standard samples for each cytokine covering the concentration range from 0.0 to $10,000 \mathrm{pg} / \mathrm{ml}$. The intra- and inter-assay precision of these cytometric bead assays typically range below $10 \%[35]$.

\section{Expression of recombinant SepS}

SepS coding sequence was amplified from a murine liver cDNA library (f-primer: AAGCTTAGAGCAGAGAGGAGCAGC, r-primer: CTCGAGCCGCCAGATGATGGGC) with proper restriction sites for in-frame cloning into pcDNA3.1-V5-His-TOPO (Invitrogen). Correct sequence and tag position were verified by DNA sequencing. The resulting construct was transfected or not into human hepatoma Huh7 cells by Ca-phosphate. Cells were harvested $48 \mathrm{~h}$ after transfection. The resulting cell lysates containing or not recombinant SepS were used as positive and negative controls in the Western Blot analyses, respectively.

\section{Western Blot Analyses}

Serum samples were collected and protein homogenates were prepared from different tissues and separated by $10 \%$ (SepP) or $15 \%$ (SepS) SDS-PAGE before being transferred to a nitrocellulose membrane (Protran, Schleicher \& Schuell, Dassel, Germany) as described [28]. Membranes were stained by Ponceau S (PonS) in order to control complete transfer and equal loading of the lanes. Relative serum albumin concentrations were determined by densitometric quantification of the major band at $67 \mathrm{kD}$. A polyclonal antiserum ( $\alpha$-SepS) was generated in rabbits by immunization with a synthetic SepS-specific peptide (Ac-GRSYKRNSGRPQEEDGPGC-amid, corresponding to residues 125-142 of murine SepS, Mus musculus histocompatibility H47 mRNA, NM_024439.3). Antibodies specific for murine SepP have been characterized before and were used as described [28]. V5-specific antibodies were purchased and used according to the manufacturer's instruction (Invitrogen).

\section{Se determination by total reflection $\mathrm{X}$-ray fluorescence analysis (TXRF)}

Aliquots of tissue homogenates $(100 \mu \mathrm{l})$ were digested with nitric acid (4 volumes, 65\%) and spiked with an internal gallium standard (Sigma). Mouse serum samples (10 $\mu 1)$ were diluted with distilled water $(40 \mu \mathrm{l})$ and spiked as above. Samples were applied to quartz glass carriers and left to dry. TXRF analyses were performed as recommended using a Picofox S2 instrument (Bruker AXS Inc. Madison, 
Wisconsin, USA). Accuracy of Se determination was verified with a mouse serum pool and a specified human serum sample (Seronorm, Billigstad, Norway). The inter-assay coefficient of variation was below $10 \%$ for samples containing Se concentrations $>100 \mu \mathrm{g} / \mathrm{l}$.

\section{Statistical analysis}

Data are expressed as mean \pm SEM. Comparisons of two groups were done with Student's $t$-test. Differences between treatment groups were analyzed by one-way analysis of variance (ANOVA) and Dunnett's or Bonferroni post hoc tests for significance as indicated in the figure legends using Graphpad Prism v4.0 software (Graphpad Software, San Diego, CA, USA). Statistical significance was defined as $\mathrm{p}<0.05(*)$, as $\mathrm{p}<0.01(* *)$ or as $\mathrm{p}<0.001(* * *)$.

\section{RESULTS}

Liver-specific induction of SepS during the acute phase response in vivo

SepS has been shown to be dynamically regulated by divergent stressors in vitro [25-27]. Therefore, we aimed to test whether SepS expression also changes during the acute phase response in vivo. To this end, a SepS-specific antiserum $(\alpha-$ SepS) was raised in rabbits and tested in Western Blot analyses. A single band of approx. $27 \mathrm{kD}$ was detected from cells transfected with a recombinant tagged SepS protein but not in control cells (Fig. 1A). Identity of the band was verified by antibodies directed against the V5 tag of the recombinant SepS protein. In vivo, a single injection of LPS induced SepS expression in liver mainly on the protein level (Fig. 1B). Relative transcript concentrations of SepS were determined by densitometric analysis of the Northern blots and remained constant in relation to $\beta$-actin signals ( $\beta$-act.) during the study period of $24 \mathrm{~h}$ after LPS injection (Fig. 1B). In comparison to liver, no effects on SepS protein concentrations were observed in brain, spleen or testes of the same mice over the time period analysed (Fig. 1C). In order to identify the cell type responsible for the upregulation of SepS protein levels in liver, a transgenic mouse line with hepatocyte-specific genetic inactivation of selenoprotein expression was studied [36]. LPS had no effects on SepS protein concentrations in the livers of these mice (Fig. 1D). These results indicate that hepatocytes are responsible for the LPS-dependent induction of SepS in liver during the acute phase response.

\section{Se-dependent sex-specific modulation of the immune response}

Se has been shown to modulate the LPS-induced oxidative stress response in murine macrophages in vitro [37]. Moreover, mice with altered selenoprotein expression display a different cytokine response than controls upon influenza virus infection [4]. Yet the selenoproteins are sex-specifically expressed $[30,38]$. We thus hypothesized that both sex and Se are important parameters for selenoprotein regulation and immune response. Therefore, we conducted a short-term Se supplementation experiment to specifically elucidate the importance of Se availability for the cytokine response and hepatic SepS expression. To this end, male and female mice were raised on a Se-poor diet during the 3 weeks before challenge to develop a marginal Se status. Then, mice were supplemented or not during their last 3 days with sodium selenite $(100 \mu \mathrm{M})$ via their drinking water and received a single injection of $\mathrm{NaCl}$ or LPS (100 $\mu \mathrm{g}$ /animal) $24 \mathrm{~h}$ before being sacrificed and analysed (Fig. 2). Circulating levels of Il-6, Mcp1 and TNF- $\alpha$ were analyzed in the individual serum samples. The LPS-injected mice displayed strongly-increased cytokine concentrations compared to the control animals in both the male and female groups (Fig. 3). Se supplementation decreased the fulminant immune response in male mice; here, the LPS-induced TNF- $\alpha$ response was decreased with borderline significance whereas the LPS-dependent inductions of Il-6 and Mcp 1 were significantly decreased on average to 50\% compared to the Se-poor male individuals. In the female groups, Se had no statistical significant effects on the LPS-induced cytokines under these conditions.

\section{Efficiency of a short term Se supplementation regimen to increase the Se status}

In order to test whether this short-term Se supplementation was effective to raise biomarkers of the Se status in the experimental mice, hepatic TxnRd, hepatic Gpx and serum Gpx3 enzyme activities and concentrations of hepatic SelS and serum SepP along with serum and hepatic Se concentrations were analysed. As expected, hepatic Gpx activities, serum and hepatic Se along with circulating SepP 
concentrations increased strongly in response to Se supplementation in both female and male mice (Fig. 4A-D). In contrast, hepatic TxnRd remained unaltered. The Se-dependent increase in serum Gpx3 activity was sex-specific under these conditions and statistically significant in males only (Fig. 4E-F). The strong effects on hepatic and circulating Se, hepatic Gpx activity and serum SepP concentrations indicate that application modus, dosage and time were sufficient to allow efficient $\mathrm{Se}$ uptake and improved hepatic selenoprotein biosynthesis and secretion under these conditions. Circulating SepP and serum Se turned out to represent robust markers of a short-term Se supplementation effect and faithfully mirrored changes in hepatic Se availability and hepatic Gpx enzyme activities while Gpx3 proved less suitable to monitor supplementation success under these conditions.

\section{Comparison of different Se-dependent biomarkers during the acute phase response}

A single sub-lethal LPS-injection represents a reliable model to analyse the acute phase response of Se and selenoproteins in experimental rodents [28, 39]. As observed before, the inflammatory stimulus caused strongly declining serum Se and SepP concentrations but had only marginal effects on serum albumin concentrations (Fig. 4A-B). Hepatic SepP mRNA concentrations remained unaffected under these conditions (data not shown) as studied before in detail [28]. LPS-dependent down regulation of serum Se and SepP concentrations were especially pronounced in the supplemented mice with higher Se status. These results verify that serum Se and SepP represent robust negative acute phase reactants. Hepatic Se concentrations were similarly strongly affected by the LPS stimulus in both sexes (Fig. 4C). In comparison, LPS affected hepatic Gpx activity in Se-supplemented male mice only (Fig. 4D). TxnRd activities in liver were not significantly affected by LPS under these conditions (Fig. 4E). The activity of kidney-derived Gpx3 remained largely unaltered by LPS in the Se-supplemented or Se-poor male or female mice (Fig. 4F). These results are consistent with the different dynamics and half-lives of circulating SepP and Gpx3 [40]. Moreover, this finding is in line with the results from a recent clinical study highlighting circulating SEPP as the presumably best biomarker for Se metabolism in sepsis [14]. In summary, SepP as a mainly hepatic product appears to be directly and strongly affected while Gpx3 as a kidney-derived and SepP-dependent secondary parameter appears to respond only poorly to LPS and the decreasing serum Se and SepP concentrations.

\section{Importance of sex and Se for SelS expression and LPS-dependent maximal induction}

In general, ample Se as substrate is needed in the form of selenocysteine-loaded tRNA in order to support biosynthesis of selenoproteins. Accordingly, SepS protein levels increased significantly in Se supplemented mice as compared to Se-poor animals (Fig. 5). In contrast to the declining hepatic Se and circulating SepP concentrations [28], LPS injection increased SepS expression in liver in both male and female animals (Fig. 1B, D and Fig. 5). Notably, a robust induction was observed in the Sepoor animals indicating that certain mechanisms within the hepatocytes can support SepS expression even against overall low Se status in a prioritized manner. In male mice, SepS expression was strongly induced by LPS under Se-poor conditions but not under Se supplemented conditions under which SepS apparently already had reached peak concentrations (Fig. 5). In contrast, maximal SepS expression in females was only observed upon LPS stimulation and Se supplementation, indicating that female mice needed higher Se concentrations or longer supplementation times in order to obtain maximal SepS expression.

\section{DISCUSSION}

The acute phase response in sepsis is a life-threatening process aiming to reprogram the organism's metabolism for defence against invading pathogens. Under such conditions, e.g. serum iron becomes strongly reduced as a meaningful reaction to deprive the proliferating microbes from one of their essential trace elements [41]. Likewise, $\mathrm{Se}$ in serum is known to decline as a negative acute phase reactant $[39,42]$. The physiological purpose for this phenomenon is currently unknown but the absence from the circulation might again deprive the pathogens from an essential component [43]. Alternatively, it might improve the ability of immune cells to fight invaders by e.g. oxidative burst processes whose effects would otherwise be dampened by selenoproteins [44]. These theories still 
need experimental proof but are in line with the reduced serum Se and SEPP concentrations under inflammatory conditions in humans $[6,13-16]$ and declining serum Se and SepP levels in experimental rodents $[28,39]$. But what processes control the negative acute phase responses of serum Se and SEPP? Comparing LPS-dependent SepP decline in serum of Se-supplemented and Se-poor mice (Fig.3B), it becomes obvious that a loss of SepP into other tissues or an extensive binding onto the surface of the blood vessels is unlikely. Otherwise a stronger and more uniform decline would have been observed, especially in the male and female animals with low Se status. Since SepP expression depends on the Se status, the declining Se concentrations in liver (Fig. 4C) argue more in favour of a reduced hepatic SepP biosynthesis rate during the acute phase response. This notion is in line with the down-regulation of important factors involved in hepatic SepP biosynthesis under inflammatory conditions [28] and the rapid and specific degradation of another hepatic selenoprotein, i.e., Sep15, during acute ER stress [45]. These findings imply that the reducing Se concentrations in serum rather represent a side-effect secondary to an altered metabolic program in liver. This interpretation is corroborated by the better survival odds of sepsis patients with high Se status and with the positive effects of Se supplementation in critically ill patients $[6,15]$.

In this light, the concurrently rising SepS concentration in liver as a positive acute phase reactant might offer a causal explanation on the fate of the missing serum Se especially in Se-poor organisms. Of note, the effects of LPS on the biosynthesis of SepP and SelS are elicited largely independent of their transcript concentrations. We have shown before that LPS impairs expression of central components of the selenoprotein biosynthesis machinery and reduces hepatic SepP production without affecting SepP mRNA concentrations [28]. Here, we report a similarly strong effect on SepS expression in liver, albeit in the opposite direction, i.e., increased protein levels again without respective LPS-effects on SepS transcript concentrations (Fig. 1B). Moreover, using the transgenic mice with cell-type specific impaired selenoprotein biosynthesis, both effects proceed simultaneously in the same cells, i.e., in hepatocytes. Obviously, hepatocytes shuttle their available Se into SepS and away from the biosynthesis of other less vital selenoproteins during the acute phase response. Such a posttranslational regulatory circuit nicely complements the diverse molecular pathways known which finally translate ER stress into the inflammatory response, i.e., rearranging the protein biosynthesis pattern via eIF $2 \alpha$ phosphorylation, translational frame-shifting and activation of XBP1 and proteolytic generation of nuclear ATF6-p50 [24]. In contrast to these effects which relay a stress signal from ER into cytoplasm and nucleus, increased biosynthesis of SepS directly improves functioning of the critical cellular compartment, i.e. ER, via its important role during the removal of misfolded proteins during ERAD $[25,27,46]$. It is the nature of SepS as a selenoprotein to depend on a sufficiently high Se status needed for increased biosynthesis. Apparently, the redirection of Se away form other selenoproteins towards SepS expression fulfils this demand both under adverse circumstances as is the case in a poorly supplied individual and during the acute phase response. The concurrent decline of serum Se might represent the price for the prioritized hepatic SepS biosynthesis under inflammatory conditions, i.e., a side-effect.

But an efficient selenoprotein biosynthesis usually profits from increased Se supply. Such support can be provided by a respectively tailored immunonutrition [47]. The positive effects of Se supplementation in the clinics imply that a readily available Se source, e.g. sodium selenite, improves acute phase response and outcome [6]. While the best regimen and selenocompound in terms of application route and dosage is a matter of discussion, a low Se status during septicaemia has uniformly been proven as a negative prognostic marker for survival odds [48, 49]. Therefore, we have attempted a short term preventive Se supplementation effort aiming to improve Se status and selenoprotein biosynthesis fast via oral application in our experiments. The data clearly indicate that this effort was successful and especially the cell-type specific up-regulation of SepS in hepatocytes relied stringently on the Se status. Both male and female mice took advantage of an increased Se supply in order to maximize SepS expression albeit with sexual dimorphic dynamics. In response to supplementation, maximal SepS levels were observed already under basal conditions in male but not in female mice. Likewise, concentrations of circulating cytokines were mitigated by Se especially in male mice.

Even though these mechanistic insights have been deduced from rodent models and not human patients, the interrelation of Se status and SepS expression might help to explain divergent findings in genetic association studies of SEPS genotype and inflammatory diseases. In this respect, strong 
associations were reported between the well characterized -105 SEPS promoter polymorphism [21] and gastric cancer susceptibility [50], coronary heart disease and stroke [51] and preeclampsia [52]. Together with the initial characterization of the interrelation of SEPS and inflammatory cytokines [21], a general effect of SEPS genotype on inflammatory diseases had been assumed. Therefore, a lack of $S E P S$ genotype-disease association as recently reported for type 1 diabetes, rheumatoid arthritis, inflammatory bowel disease or ulcerative colitis [53] was surprising. Here, the generalized conclusion might be misleading since the data have not been corrected for by sex and the actual Se status of the probands. Our results highlight the importance of these parameters for immune response, cytokine patterns and SEPS induction. Congruent data on the interaction of genotype, sex and Se status were recently reported for SEPP isoform expression in human cancer [54]. Since the observed inflammatory effects on SEPP and SELS biosynthesis are mainly exerted on the post-transcriptional level, the Se status and the concentration of selenocysteine-loaded tRNA are decisive parameter for the diseasespecific response. According to our results, it seems advisable to determine the Se status along with the SEPS genotype in future studies to be better able to compare the genotype-disease association in men and women and gain knowledge on the potential benefit of a personally tailored $\mathrm{Se}$ supplementation in a specific pathology. The herein proposed preventive measure to increase the Se status fast via an orally available supplement might prove useful in the clinics to ensuring optimal physiological ER stress response by high SEPS expression prior to a potential challenge. At the same time the unfavourable low circulating Se concentrations can be avoided. Respective clinical studies taking the Se status and sex into account appear necessary and are highly recommended.

\section{Acknowledgements}

The excellent technical assistance of Anita Kinne, Birgit Hollenbach and Jazmin Chiu is gratefully acknowledged. We thank Drs. D.L. Hatfield and B.A. Carlson for generously sharing the transgenic mice, Drs. J. Köhrle, U. Schweizer, P.J. Hofmann and E.K. Wirth for stimulating discussions and help with the experiments, and Deutsche Forschungsgemeinschaft DFG [Scho849/2-2, GraKo1208], Charité Berlin [personal grant to LS] and Deutsche Krebshilfe [10-1792 SchoII] for financial support.

\section{REFERENCES}

1 Hatfield, D. L., Carlson, B. A., Xu, X. M., Mix, H. and Gladyshev, V. N. (2006) Selenocysteine incorporation machinery and the role of selenoproteins in development and health. Prog Nucleic Acid Res Mol Biol 81, 97-142

2 Papp, L. V., Lu, J., Holmgren, A. and Khanna, K. K. (2007) From selenium to selenoproteins: synthesis, identity, and their role in human health. Antioxid Redox Signal 9, 775-806

3 Broome, C. S., McArdle, F., Kyle, J. A., Andrews, F., Lowe, N. M., Hart, C. A., Arthur, J. R. and Jackson, M. J. (2004) An increase in selenium intake improves immune function and poliovirus handling in adults with marginal selenium status. Am J Clin Nutr 80, 154-162

4 Sheridan, P. A., Zhong, N., Carlson, B. A., Perella, C. M., Hatfield, D. L. and Beck, M. A. (2007) Decreased selenoprotein expression alters the immune response during influenza virus infection in mice. J Nutr 137, 1466-1471

5 Hoffmann, P. R. and Berry, M. J. (2008) The influence of selenium on immune responses. Mol Nutr Food Res 52, 1273-1280

6 Angstwurm, M. W., Engelmann, L., Zimmermann, T., Lehmann, C., Spes, C. H., Abel, P., Strauss, R., Meier-Hellmann, A., Insel, R., Radke, J., Schüttler, J. and Gärtner, R. (2007) Selenium in Intensive Care (SIC): results of a prospective randomized, placebo-controlled, multiple-center study in patients with severe systemic inflammatory response syndrome, sepsis, and septic shock. Crit Care Med 35, 118-126

7 Hurwitz, B. E., Klaus, J. R., Llabre, M. M., Gonzalez, A., Lawrence, P. J., Maher, K. J., Greeson, J. M., Baum, M. K., Shor-Posner, G., Skyler, J. S. and Schneiderman, N. (2007) Suppression of human immunodeficiency virus type 1 viral load with selenium supplementation: a randomized controlled trial. Arch Intern Med 167, 148-154 
8 Schomburg, L. and Köhrle, J. (2008) On the importance of selenium and iodine metabolism for thyroid hormone biosynthesis and human health. Mol Nutr Food Res 52, 1235-1246

9 Hesketh, J. (2008) Nutrigenomics and selenium: gene expression patterns, physiological targets, and genetics. Annu Rev Nutr 28, 157-177

10 Rayman, M. P. (2009) Selenoproteins and human health: insights from epidemiological data. Biochim Biophys Acta 1790, 1533-1540

11 Ashton, K., Hooper, L., Harvey, L. J., Hurst, R., Casgrain, A. and Fairweather-Tait, S. J. (2009) Methods of assessment of selenium status in humans: a systematic review. Am J Clin Nutr 89, 2025S-2039S

12 Burk, R. F. and Hill, K. E. (2005) Selenoprotein P: an extracellular protein with unique physical characteristics and a role in selenium homeostasis. Annu Rev Nutr 25, 215-235

13 Hollenbach, B., Morgenthaler, N. G., Struck, J., Alonso, C., Bergmann, A., Köhrle, J. and Schomburg, L. (2008) New Assay for the Measurement of Selenoprotein P as a Sepsis Biomarker from Serum. J Trace Elem Med Biol 22, 24-31

14 Forceville, X., Mostert, V., Pierantoni, A., Vitoux, D., Le Toumelin, P., Plouvier, E., Dehoux, M., Thuillier, F. and Combes, A. (2009) Selenoprotein P, Rather than Glutathione Peroxidase, as a Potential Marker of Septic Shock and Related Syndromes. Eur Surg Res 43, 338-347

15 Forceville, X., Vitoux, D., Gauzit, R., Combes, A., Lahilaire, P. and Chappuis, P. (1998) Selenium, systemic immune response syndrome, sepsis, and outcome in critically ill patients. Crit Care Med 26, 1536-1544

16 Sakr, Y., Reinhart, K., Bloos, F., Marx, G., Russwurm, S., Bauer, M. and Brunkhorst, F. (2007) Time course and relationship between plasma selenium concentrations, systemic inflammatory response, sepsis, and multiorgan failure. Br J Anaesth 98, 775-784

17 Manzanares, W., Biestro, A., Galusso, F., Torre, M. H., Manay, N., Pittini, G., Facchin, G. and Hardy, G. (2009) Serum selenium and glutathione peroxidase-3 activity: biomarkers of systemic inflammation in the critically ill? Intensive Care Med 35, 882-889

18 Gärtner, R. (2009) Selenium and thyroid hormone axis in critical ill states: an overview of conflicting view points. J Trace Elem Med Biol 23, 71-74

19 Wang, Z., Forceville, X., Van Antwerpen, P., Piagnerelli, M., Ahishakiye, D., Macours, P., De Backer, D., Neve, J. and Vincent, J. L. (2009) A large-bolus injection, but not continuous infusion of sodium selenite improves outcome in peritonitis. Shock 32, 140-146

20 Schomburg, L. (2009) Selenium in sepsis - why do we need a strong and fast supplementation? Shock, in press

21 Curran, J. E., Jowett, J. B., Elliott, K. S., Gao, Y., Gluschenko, K., Wang, J., Abel Azim, D. M., Cai, G., Mahaney, M. C., Comuzzie, A. G., Dyer, T. D., Walder, K. R., Zimmet, P., MacCluer, J. W., Collier, G. R., Kissebah, A. H. and Blangero, J. (2005) Genetic variation in selenoprotein S influences inflammatory response. Nat Genet 37, 1234-1241

22 Meusser, B., Hirsch, C., Jarosch, E. and Sommer, T. (2005) ERAD: the long road to destruction. Nat Cell Biol 7, 766-772

23 Todd, D. J., Lee, A. H. and Glimcher, L. H. (2008) The endoplasmic reticulum stress response in immunity and autoimmunity. Nat Rev Immunol 8, 663-674

24 Zhang, K. and Kaufman, R. J. (2008) From endoplasmic-reticulum stress to the inflammatory response. Nature 454, 455-462

25 Gao, Y., Feng, H. C., Walder, K., Bolton, K., Sunderland, T., Bishara, N., Quick, M., Kantham, L. and Collier, G. R. (2004) Regulation of the selenoprotein SelS by glucose deprivation and endoplasmic reticulum stress - SelS is a novel glucose-regulated protein. FEBS Lett 563, 185-190

26 Gao, Y., Hannan, N. R., Wanyonyi, S., Konstantopolous, N., Pagnon, J., Feng, H. C., Jowett, J. B., Kim, K. H., Walder, K. and Collier, G. R. (2006) Activation of the selenoprotein SEPS1 gene expression by pro-inflammatory cytokines in HepG2 cells. Cytokine 33, 246-251

27 Kim, K. H., Gao, Y., Walder, K., Collier, G. R., Skelton, J. and Kissebah, A. H. (2007) SEPS1 protects RAW264.7 cells from pharmacological ER stress agent-induced apoptosis. Biochem Biophys Res Commun 354, 127-132

28 Renko, K., Hofmann, P. J., Stoedter, M., Hollenbach, B., Behrends, T., Köhrle, J., Schweizer, U. and Schomburg, L. (2009) Down-regulation of the hepatic selenoprotein biosynthesis machinery impairs selenium metabolism during the acute phase response in mice. Faseb J 23, 1758-1765 
29 Emmerson, A. M., Enstone, J. E., Griffin, M., Kelsey, M. C. and Smyth, E. T. (1996) The Second National Prevalence Survey of infection in hospitals--overview of the results. J Hosp Infect 32, 175-190

30 Riese, C., Michaelis, M., Mentrup, B., Götz, F., Köhrle, J., Schweizer, U. and Schomburg, L. (2006) Selenium-dependent pre- and posttranscriptional mechanisms are responsible for sexual dimorphic expression of selenoproteins in murine tissues. Endocrinology 147, 5883-5892

31 Moustafa, M. E., Kumaraswamy, E., Zhong, N., Rao, M., Carlson, B. A. and Hatfield, D. L. (2003) Models for assessing the role of selenoproteins in health. J Nutr 133, 2494S-2496S

32 Streckfuss, F., Hamann, I., Schomburg, L., Michaelis, M., Sapin, R., Klein, M. O., Köhrle, J. and Schweizer, U. (2005) Hepatic deiodinase activity is dispensable for the maintenance of normal circulating thyroid hormone levels in mice. Biochem Biophys Res Commun 337, 739-745

33 Renko, K., Werner, M., Renner-Muller, I., Cooper, T. G., Yeung, C. H., Hollenbach, B., Scharpf, M., Köhrle, J., Schomburg, L. and Schweizer, U. (2008) Hepatic selenoprotein P (SePP) expression restores selenium transport and prevents infertility and motor-incoordination in Seppknockout mice. Biochem J 409, 741-749

34 Schomburg, L., Schweizer, U., Holtmann, B., Flohé, L., Sendtner, M. and Köhrle, J. (2003) Gene disruption discloses role of selenoprotein $\mathrm{P}$ in selenium delivery to target tissues. Biochem $\mathrm{J} \mathbf{3 7 0}$, 397-402

35 Morgan, E., Varro, R., Sepulveda, H., Ember, J. A., Apgar, J., Wilson, J., Lowe, L., Chen, R., Shivraj, L., Agadir, A., Campos, R., Ernst, D. and Gaur, A. (2004) Cytometric bead array: a multiplexed assay platform with applications in various areas of biology. Clin Immunol 110, 252266

36 Carlson, B. A., Novoselov, S. V., Kumaraswamy, E., Lee, B. J., Anver, M. R., Gladyshev, V. N. and Hatfield, D. L. (2004) Specific excision of the selenocysteine tRNA[Ser]Sec (Trsp) gene in mouse liver demonstrates an essential role of selenoproteins in liver function. J Biol Chem 279, 8011-8017

37 Kim, S. H., Johnson, V. J., Shin, T. Y. and Sharma, R. P. (2004) Selenium attenuates lipopolysaccharide-induced oxidative stress responses through modulation of p38 MAPK and NFkappaB signaling pathways. Exp Biol Med (Maywood) 229, 203-213

38 Schomburg, L. and Schweizer, U. (2009) Hierarchical regulation of selenoprotein expression and sex-specific effects of selenium. Biochim Biophys Acta 1790, 1453-1462

39 Maehira, F., Luyo, G. A., Miyagi, I., Oshiro, M., Yamane, N., Kuba, M. and Nakazato, Y. (2002) Alterations of serum selenium concentrations in the acute phase of pathological conditions. Clin Chim Acta 316, 137-146

40 Burk, R. F., Hill, K. E., Read, R. and Bellew, T. (1991) Response of rat selenoprotein P to selenium administration and fate of its selenium. Am J Physiol 261, E26-30

41 Prentice, A. M., Ghattas, H. and Cox, S. E. (2007) Host-pathogen interactions: can micronutrients tip the balance? J Nutr 137, 1334-1337

42 Nichol, C., Herdman, J., Sattar, N., O'Dwyer, P. J., St, J. O. R. D., Littlejohn, D. and Fell, G. (1998) Changes in the concentrations of plasma selenium and selenoproteins after minor elective surgery: further evidence for a negative acute phase response? Clin Chem 44, 1764-1766

43 Stock, T. and Rother, M. (2009) Selenoproteins in Archaea and Gram-positive bacteria. Biochim Biophys Acta 1790, 1520-1532

44 Steinbrenner, H. and Sies, H. (2009) Protection against reactive oxygen species by selenoproteins. Biochim Biophys Acta 1790, 1478-1485

45 Labunskyy, V. M., Yoo, M. H., Hatfield, D. L. and Gladyshev, V. N. (2009) Sep15, a thioredoxinlike selenoprotein, is involved in the unfolded protein response and differentially regulated by adaptive and acute ER stresses. Biochemistry 48, 8458-8465

46 Ye, Y., Shibata, Y., Yun, C., Ron, D. and Rapoport, T. A. (2004) A membrane protein complex mediates retro-translocation from the ER lumen into the cytosol. Nature 429, 841-847

47 Calder, P. C. (2007) Immunonutrition in surgical and critically ill patients. Br J Nutr 98 Suppl 1, S133-139

48 Geoghegan, M., McAuley, D., Eaton, S. and Powell-Tuck, J. (2006) Selenium in critical illness. Curr Opin Crit Care 12, 136-141 
49 Berger, M. M. and Chiolero, R. L. (2007) Antioxidant supplementation in sepsis and systemic inflammatory response syndrome. Crit Care Med 35, S584-590

50 Shibata, T., Arisawa, T., Tahara, T., Ohkubo, M., Yoshioka, D., Maruyama, N., Fujita, H., Kamiya, Y., Nakamura, M., Nagasaka, M., Iwata, M., Takahama, K., Watanabe, M. and Hirata, I. (2009) Selenoprotein S (SEPS1) gene -105G $>$ A promoter polymorphism influences the susceptibility to gastric cancer in the Japanese population. BMC Gastroenterol 9, 2

51 Alanne, M., Kristiansson, K., Auro, K., Silander, K., Kuulasmaa, K., Peltonen, L., Salomaa, V. and Perola, M. (2007) Variation in the selenoprotein S gene locus is associated with coronary heart disease and ischemic stroke in two independent Finnish cohorts. Hum Genet 122, 355-365

52 Moses, E. K., Johnson, M. P., Tommerdal, L., Forsmo, S., Curran, J. E., Abraham, L. J., Charlesworth, J. C., Brennecke, S. P., Blangero, J. and Austgulen, R. (2008) Genetic association of preeclampsia to the inflammatory response gene SEPS1. Am J Obstet Gynecol 198, 336 e331335

53 Martinez, A., Santiago, J. L., Varade, J., Marquez, A., Lamas, J. R., Mendoza, J. L., de la Calle, H., Diaz-Rubio, M., de la Concha, E. G., Fernandez-Gutierrez, B. and Urcelay, E. (2008) Polymorphisms in the selenoprotein $\mathrm{S}$ gene: lack of association with autoimmune inflammatory diseases. BMC Genomics 9, 329

54 Meplan, C., Nicol, F., Burtle, B. T., Crosley, L. K., Arthur, J. R., Mathers, J. C. and Hesketh, J. E. (2009) Relative abundance of selenoprotein $P$ isoforms in human plasma depends on genotype, se intake, and cancer status. Antioxid Redox Signal 11, 2631-2640 


\section{FIGURE LEGENDS}

\section{Figure 1 Tissue-specific acute phase regulation of SepS expression in vivo}

(A) The new SepS-antiserum yields strong signals in cells positively transfected with recombinant V5tagged SepS (lanes 2-5) but not in control cells (lanes 1,6). Position of immunoreactive SepS colocalized with V5-signals and the theoretical size of the recombinant protein verifying suitability of the antibodies for SepS analysis. (B) Time-course analysis of hepatic SepS protein (top) and mRNA (bottom) concentrations after LPS- injection. Male mice $(n=4$ per group) received a single injection of saline (C) or LPS (100 $\mu \mathrm{g} / \mathrm{mouse})$ and were sacrificed after $6 \mathrm{~h}$ (all controls) or after the indicated periods of time. Samples were analyzed by two Western and two Northern blots of which a representative result is shown. Liver protein extracts from the individual mice were analyzed by Western blotting (top) and SepS amounts were quantified by densitometry. Ponceau S (PonS) staining served to control for efficient protein transfer onto the membrane and equal loading of the lanes. RNA (bottom) was isolated from the same livers and used for Northern analysis of SepS and $\beta$-actin ( $\beta$-act). $* \mathrm{P}<0.05, * * \mathrm{P}<0.01$ (one-way ANOVA with Dunnett's post hoc test). (C) Tissue-specificity of LPS effects on SepS up-regulation. Protein extracts $(n=3)$ from brain, spleen and testes of the experimental mice in (B) were analyzed by Western blot at different time intervals after injection of LPS. Recombinant SepS served as positive control (+). No significant effects of LPS on SepS protein concentrations were observed in these tissues. (D) Effects of LPS on SepS expression in wild-type (wt) and transgenic (KO) mice. Protein extracts from livers of treated (LPS) and control (C) mice were analyzed by Western blot. Recombinant SepS protein served as positive control (+). Transgenic mice $(n=5)$ with albumin-promoter driven Cre expression causing genetic deletion of the Sec-specific tRNA in hepatocytes express little SepS compared to wt $(n=5)$ animals (wt $\mathrm{C}$ vs. KO C). SepS expression is not stimulated by LPS in livers of KO mice $(n=3)$ compared to saline-injected KO controls $(n=2)$ indicating that hepatocytes account for increased SepS expression in liver of wt mice during an acute phase response in vivo. $* * \mathrm{P}<0.01$ (one-way ANOVA with Bonferroni's post hoc test).

\section{Figure 2 Experimentation scheme to study Se-dependent acute phase response}

Male and female mice were bred on regular diet and transferred to a Se-poor diet $(0.1 \mathrm{ppm} \mathrm{Se})$ at the age of 45 days (P45) on which they remained for the next 3 weeks. Then, groups of animals $(n=6$ per sex) were supplemented or not with selenite in drinking water $(100 \mu \mathrm{M})$ for 2 days prior to $\mathrm{NaCl}$ (control) or LPS injection (100 $\mu$ g/animal, i.p.) yielding 4 experimental groups (far right). Acute phase responses of cytokines, Se and selenoproteins were studied $24 \mathrm{~h}$ after injection of $\mathrm{NaCl}$ or LPS.

Figure 3 Inflammatory cytokines in control and Se supplemented mice after LPS injection Serum samples from control and experimental female (left row) and male (right row) mice ( $\mathrm{n}=6$ per group) were analysed for circulating concentrations of Il-6, Mcp1 and TNF- $\alpha$. The LPS injection increased serum cytokine concentrations in mice independent of sex. Supplementation of Se mitigated the profound immune response in male but not in female mice, especially pronounced in case of Il-6 and Mcp1. $* \mathrm{P}<0.05, * * \mathrm{P}<0.01$ (Student's $t$-test).

\section{Figure 4 Biomarkers of Se status after Se supplementation and LPS injection}

(A) Selenite supplementation increased serum Se concentrations in male and female mice ( $\mathrm{n}=6$ per group). LPS injection reduced serum Se strongly in the Se-supplemented mice of both sexes while the effect was not significant in Se-poor animals. (B) Serum levels of SepP increased after Se supplementation as determined by Western blot analysis with antibodies against murine SepP $(\alpha-$ SepP). Ponceau S (PonS) staining (top) verifies constant loading of the serum samples and comparable serum protein amounts in the lanes. Western result of pooled serum samples is shown (top). Quantification of the effects (bottom) was based on additional Western blot analyses with individual samples ( $n=6$ per group). A marginal but significant effect of LPS was observed on albumin concentrations in serum of male mice $\left({ }^{*} \mathrm{P}<0.05\right.$, Student's $t$ test). Albumin concentrations in female mice were not affected. LPS caused a significant decline in circulating SepP especially in the Sesupplemented male and female mice. $* * \mathrm{P}<0.01$ (Student's $t$-test). (C) Se concentrations in livers mirror changes in circulating SepP upon selenite and LPS treatment. Se supplementation increased hepatic Se concentrations in all groups of mice. LPS injection caused a strong decline in hepatic Se 
concentrations in the Se-supplemented male and female mice but not in Se-poor animals. (D) Hepatic Gpx activity increased by Se supplementation in both female and male mice and declined in response to LPS in male mice only. (E) Hepatic TxnRd activity was similar in male and female mice and remained unaffected by short-term selenite supplementation or LPS treatment in these experiments. (F) Gpx3 activity was determined from the serum samples. Only male mice displayed significantly increased Gpx3 activities in response to the short term oral Se supplementation. LPS had no consistent effect on circulating Gpx3 under these experimental conditions in male or female mice. $* \mathrm{P}<0.05$, $* * \mathrm{P}$ $<0.01, * * * \mathrm{P}<0.001$ (one-way ANOVA with Bonferroni's post hoc test).

Figure 5 Sex-specific regulation of hepatic SepS in response to selenite and LPS treatment LPS injection induced maximal SepS concentrations in Se-supplemented mice indicating the importance of the Se status for SepS expression. A Western blot of pooled homogenates from the livers of the experimental mice is depicted (top) in order to provide an overview. SepS protein concentrations were determined from two additional Western analyses from samples of individual mice which are shown (bottom) together with the quantification (graph). Characteristic sex-specific differences were observed with respect to both basal SepS expression levels and responsiveness to Se and LPS. $* \mathrm{P}<0.05, * * \mathrm{P}<0.01, * * * \mathrm{P}<0.001$ (Student's $t$-test). 
Fig. 1A

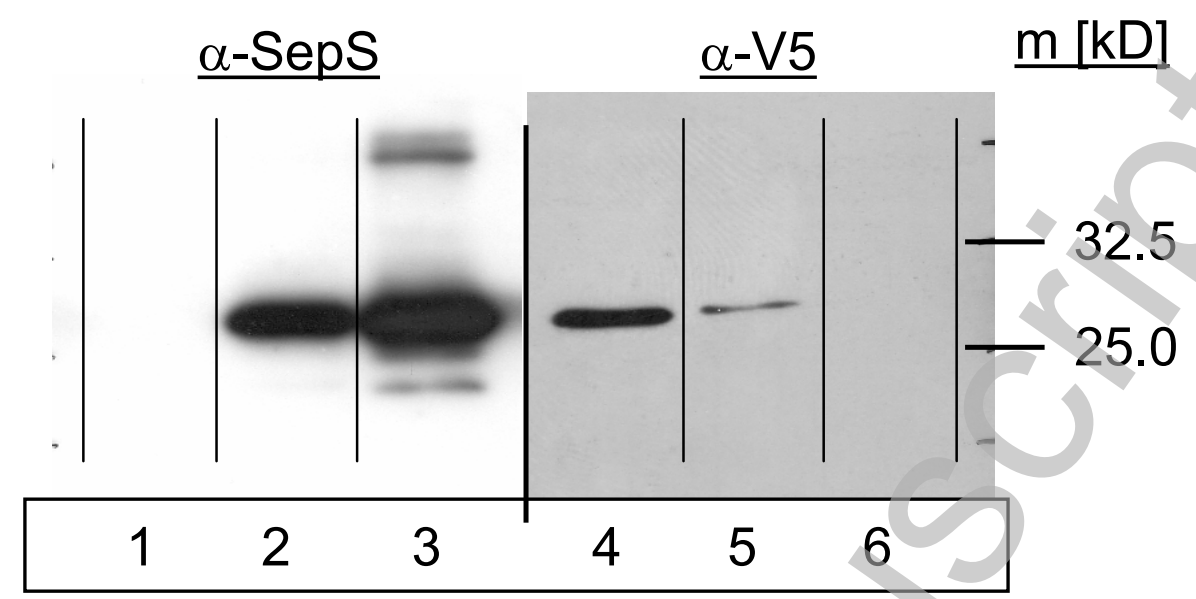

Fig. 1B

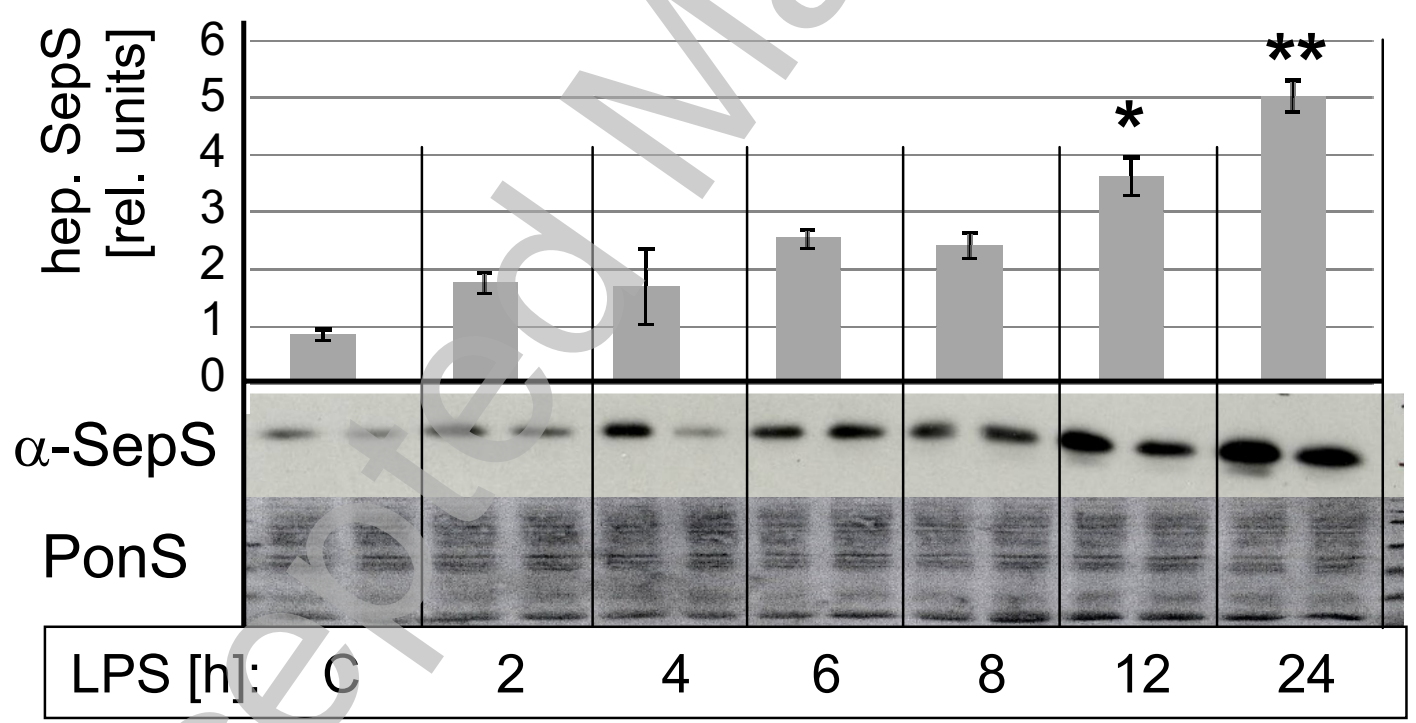

SepS mRNA

$\beta$-act mRNA

$\begin{array}{llllllll}\text { LPS [h]: } & \mathrm{C} & 2 & 4 & 6 & 8 & 12 & 24\end{array}$


Fig. 1C

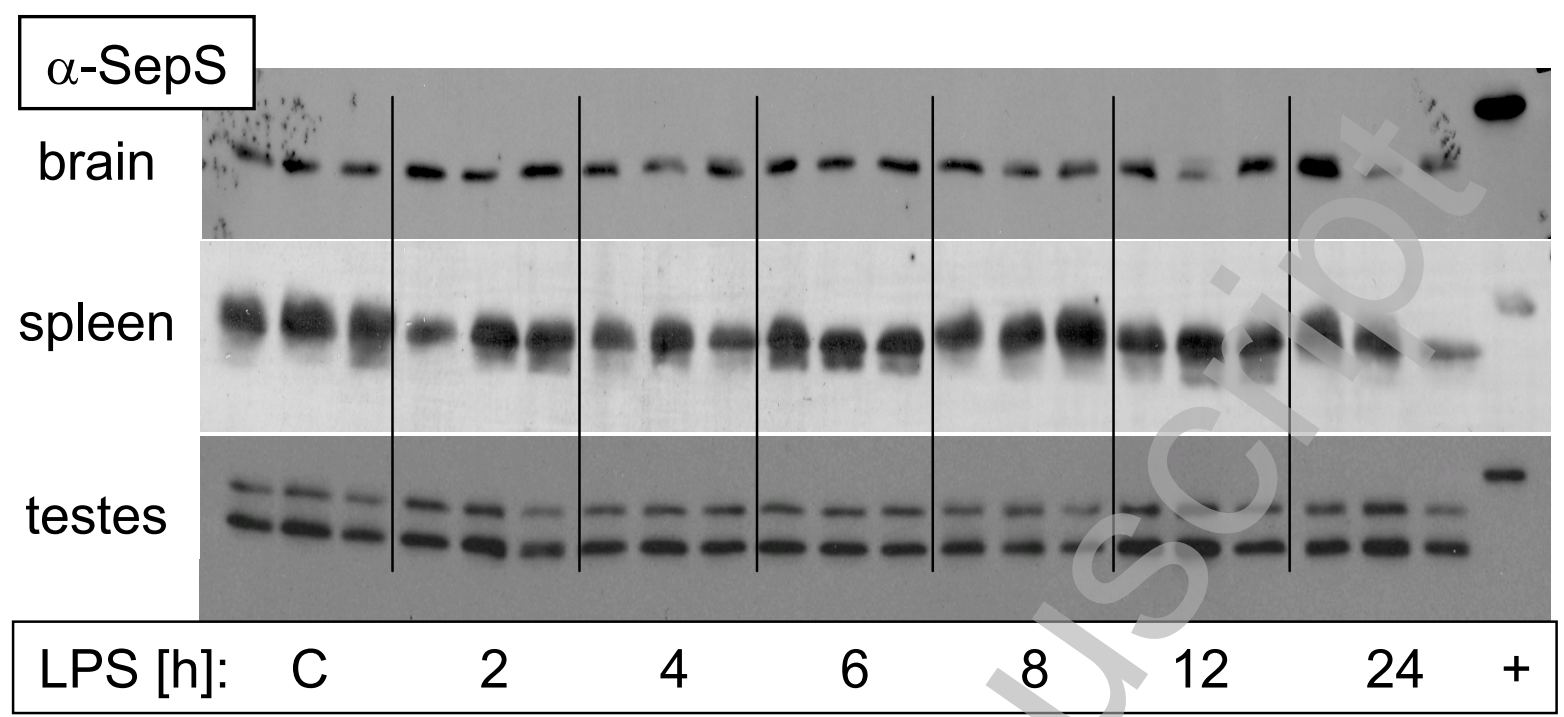

Fig. 1D
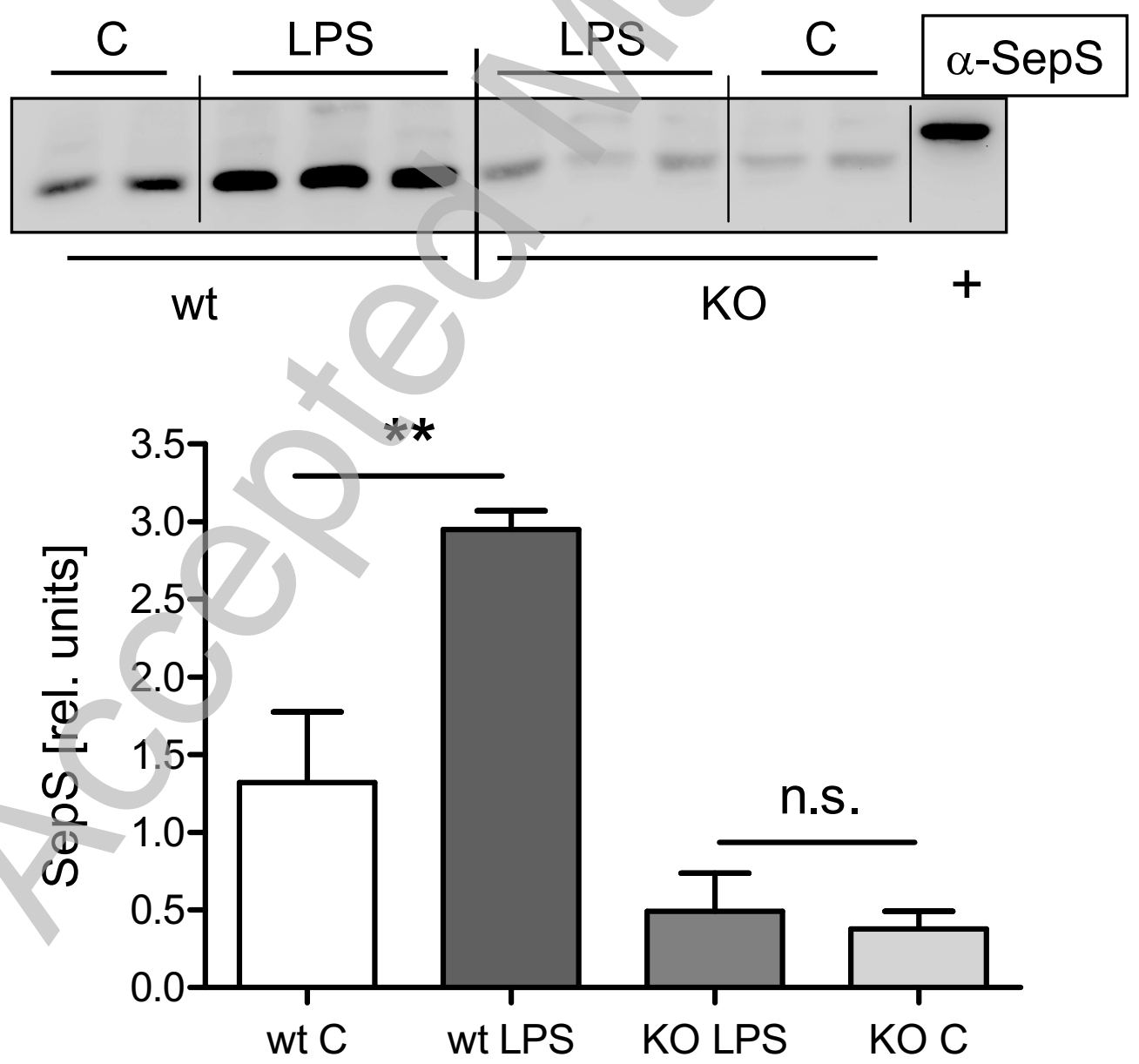
Fig. 2

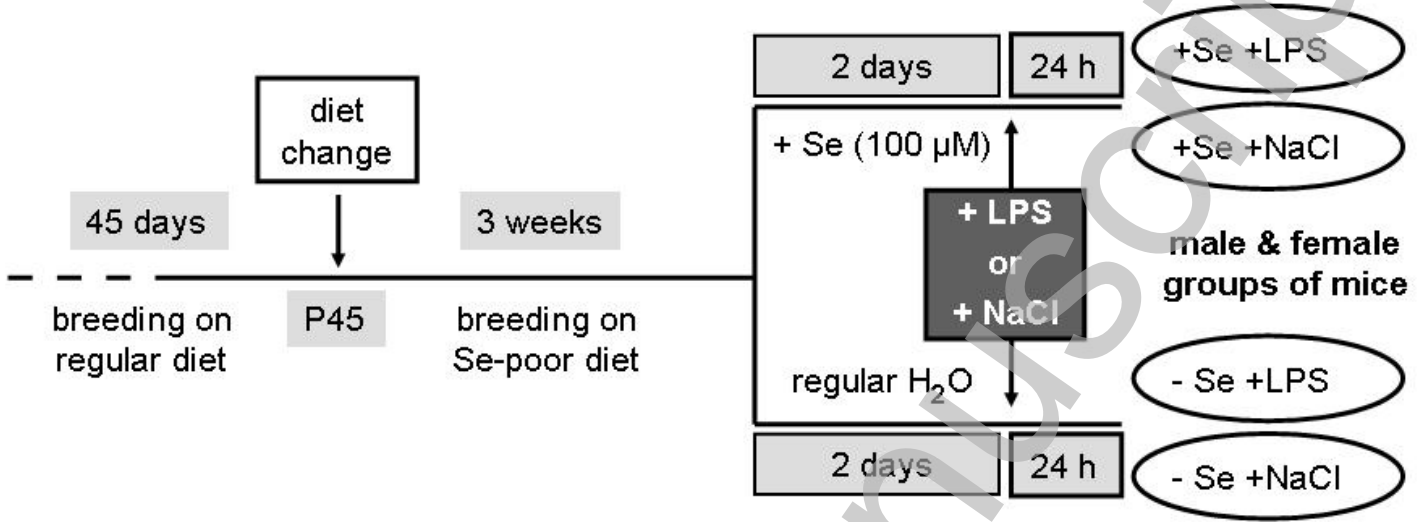


Fig. 3
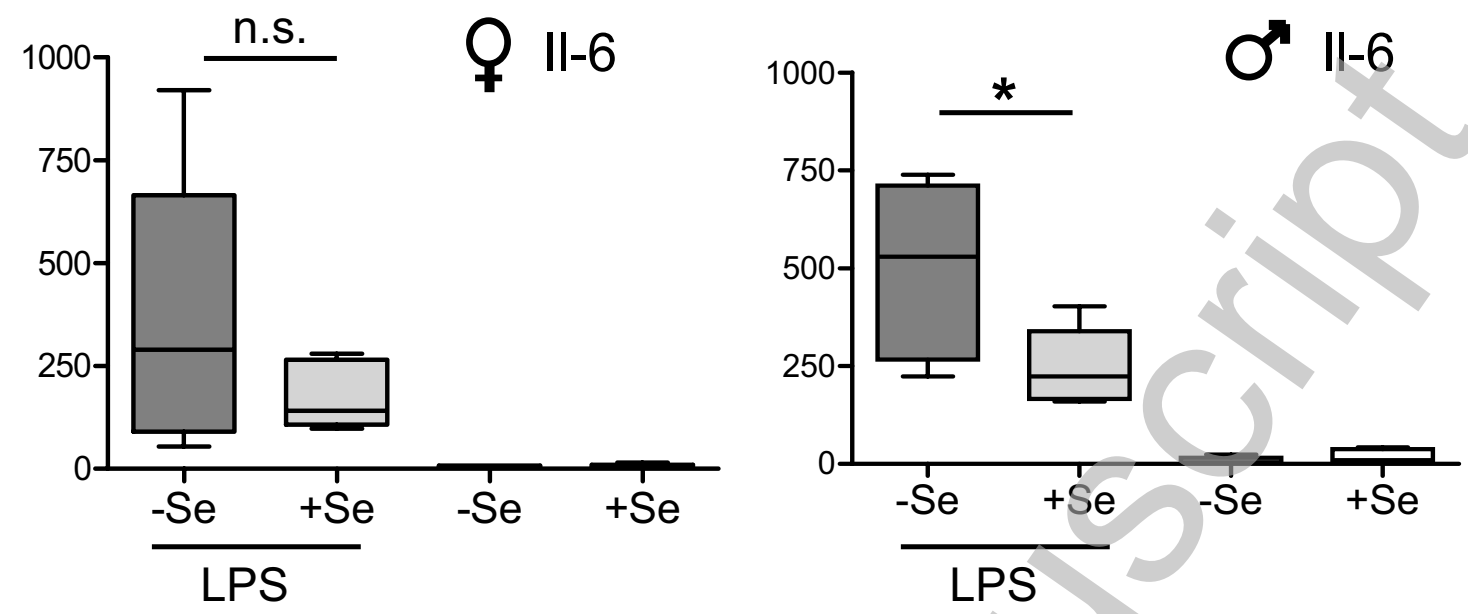

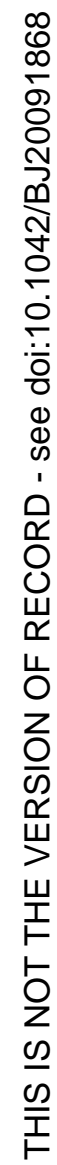
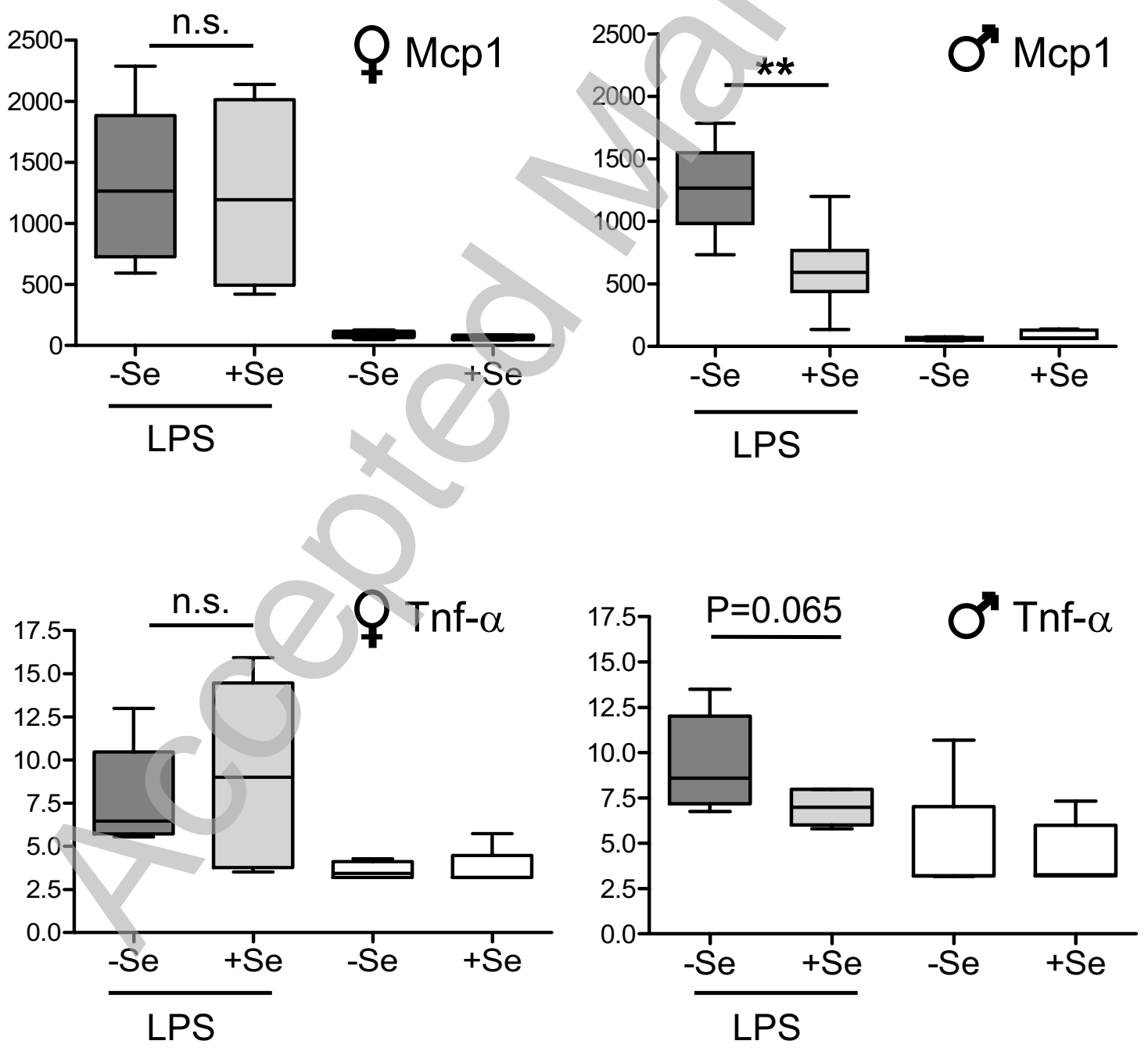
Fig. $4 \mathrm{~A}$

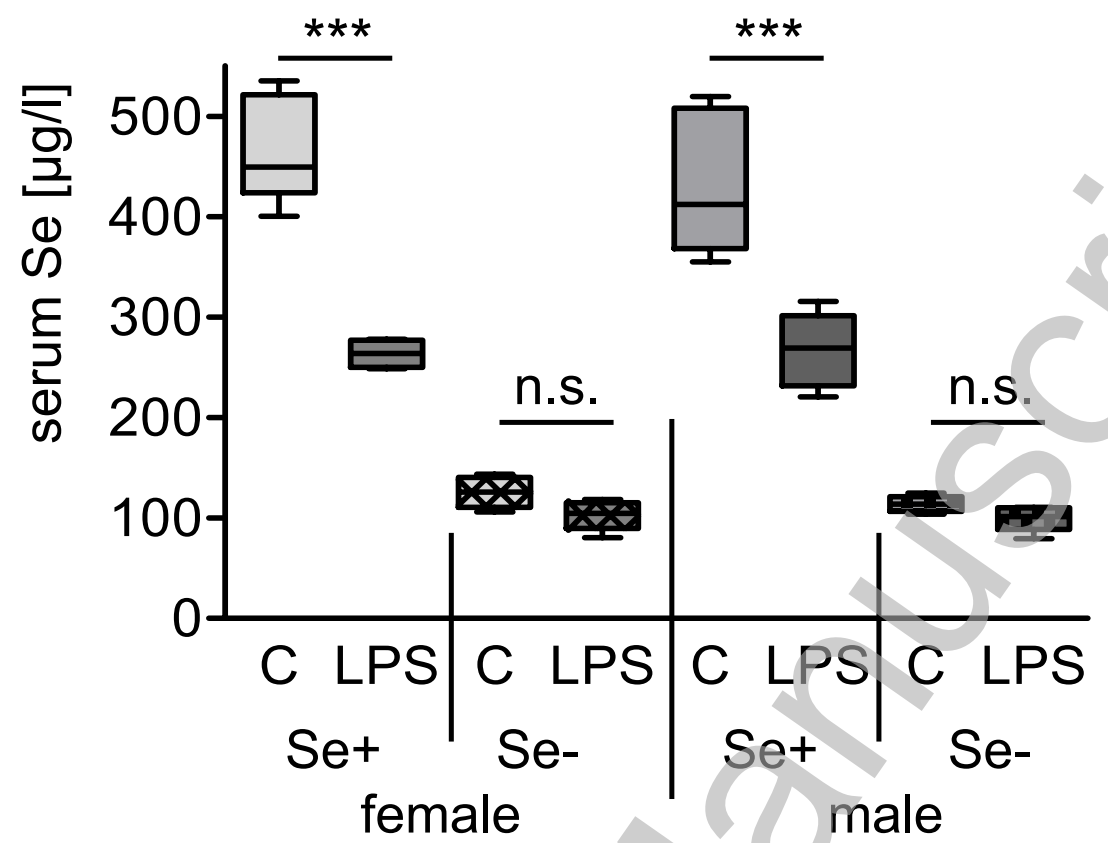


Fig. 4B

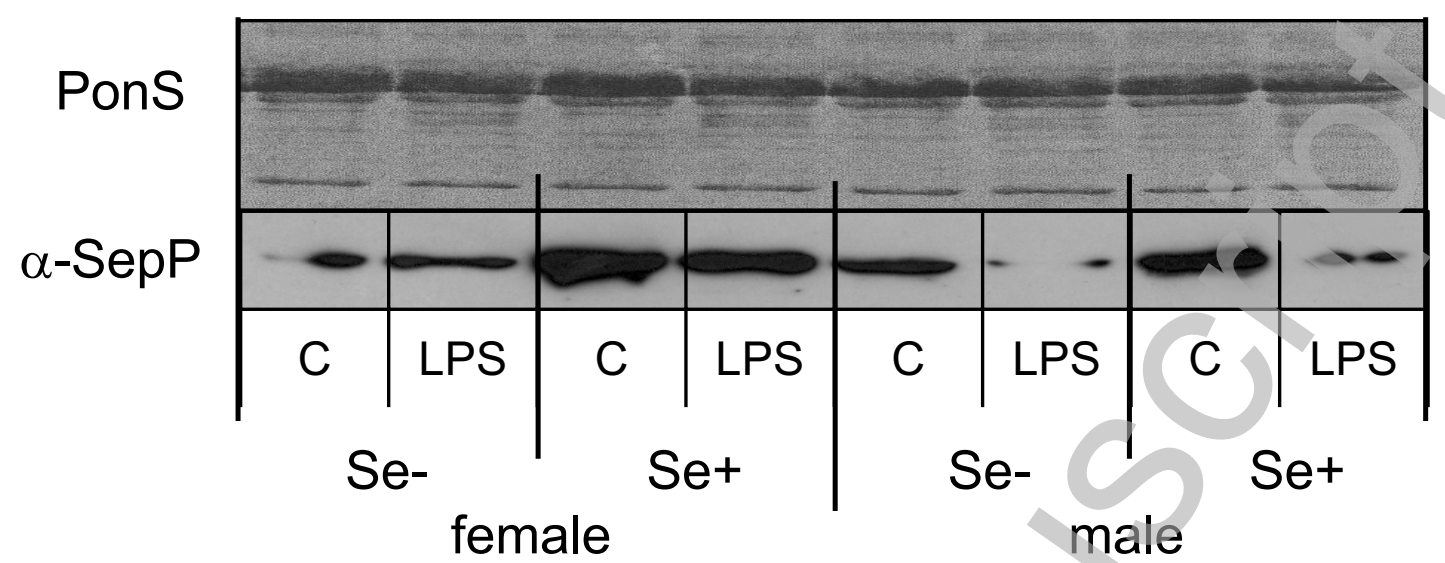

\begin{tabular}{|c|c|c|}
\hline \multicolumn{3}{|l|}{ albumin [rel. units/ $\mu \mathrm{l} \pm \mathrm{SEM}]$} \\
\hline female Se- & $1.00 \pm 0.01$ & $1.02 \pm 0.02$ \\
\hline female Se+ & $1.00 \pm 0.02$ & $1.00 \pm 0.02$ \\
\hline male Se- & $1.00 \pm 0.01$ & $0.96 \pm 0.03^{*}$ \\
\hline male Se+ & $1.00 \pm 0.02$ & $0.95 \pm 0.02^{*}$ \\
\hline
\end{tabular}

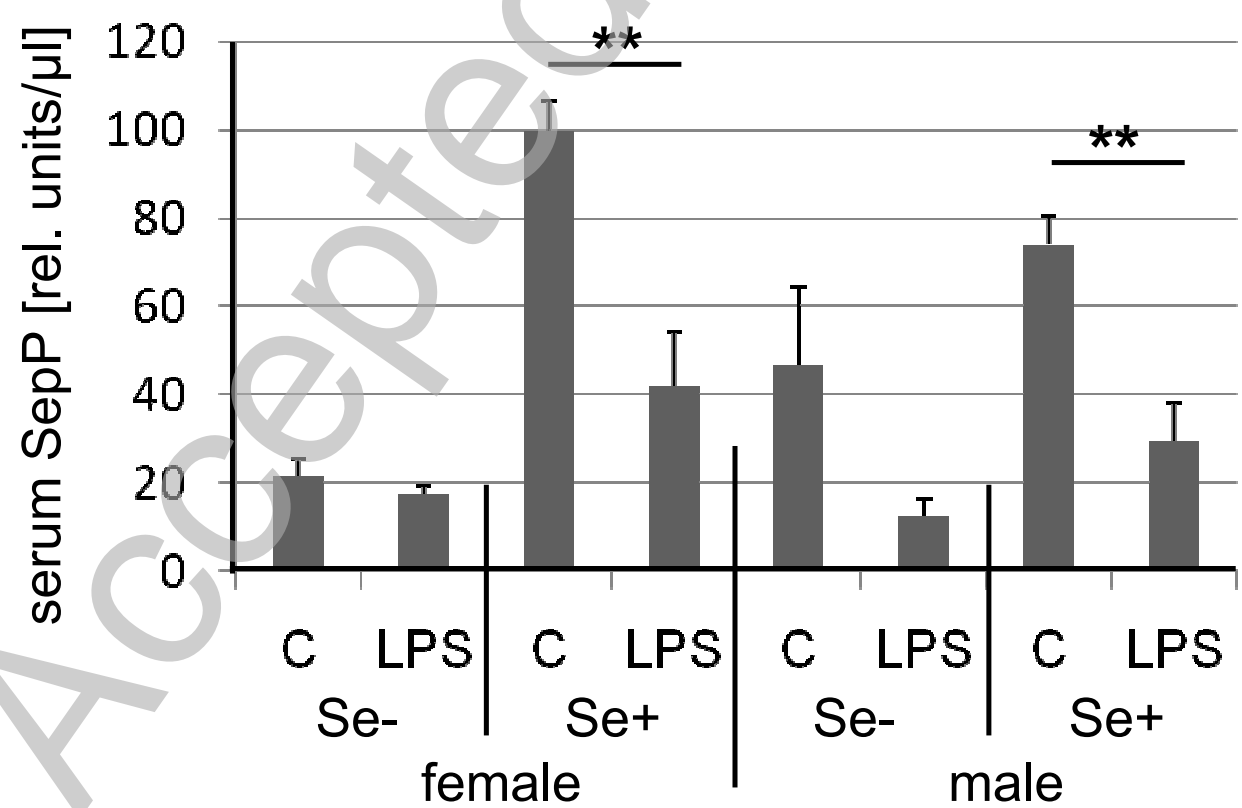


Fig. 4C

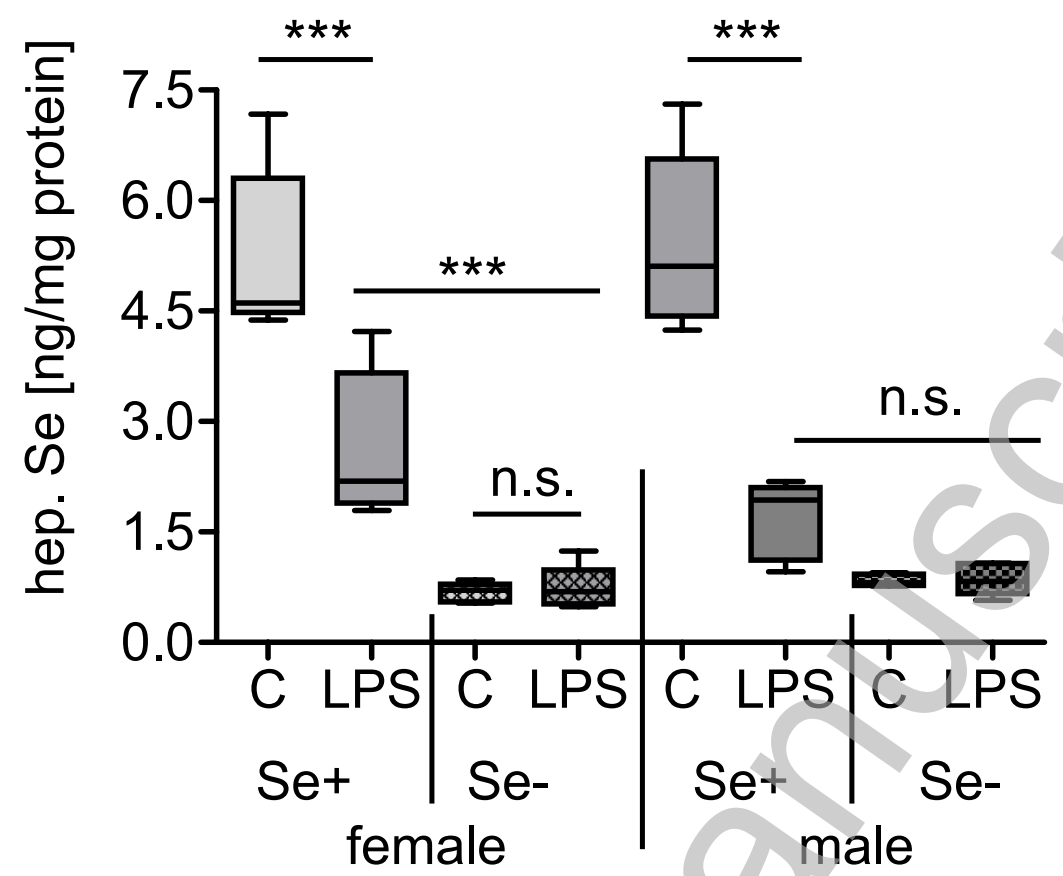

Fig. 4D

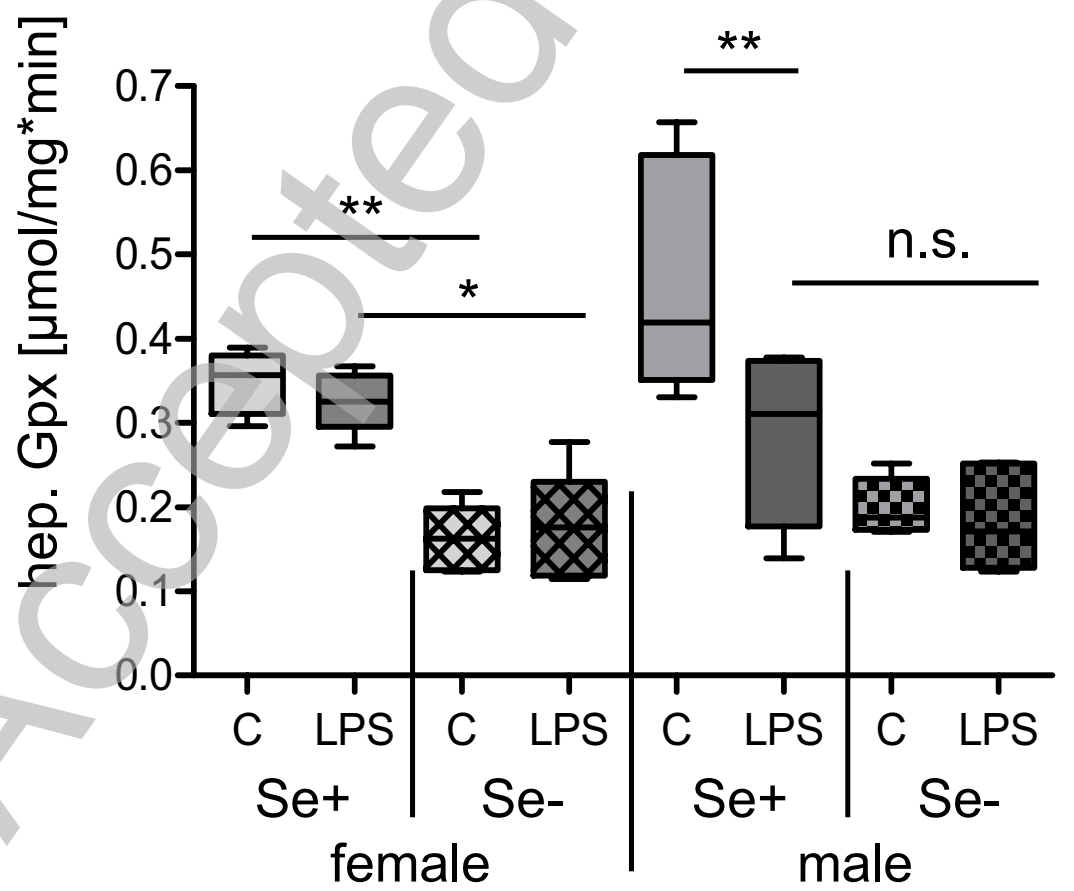


Fig. 4E

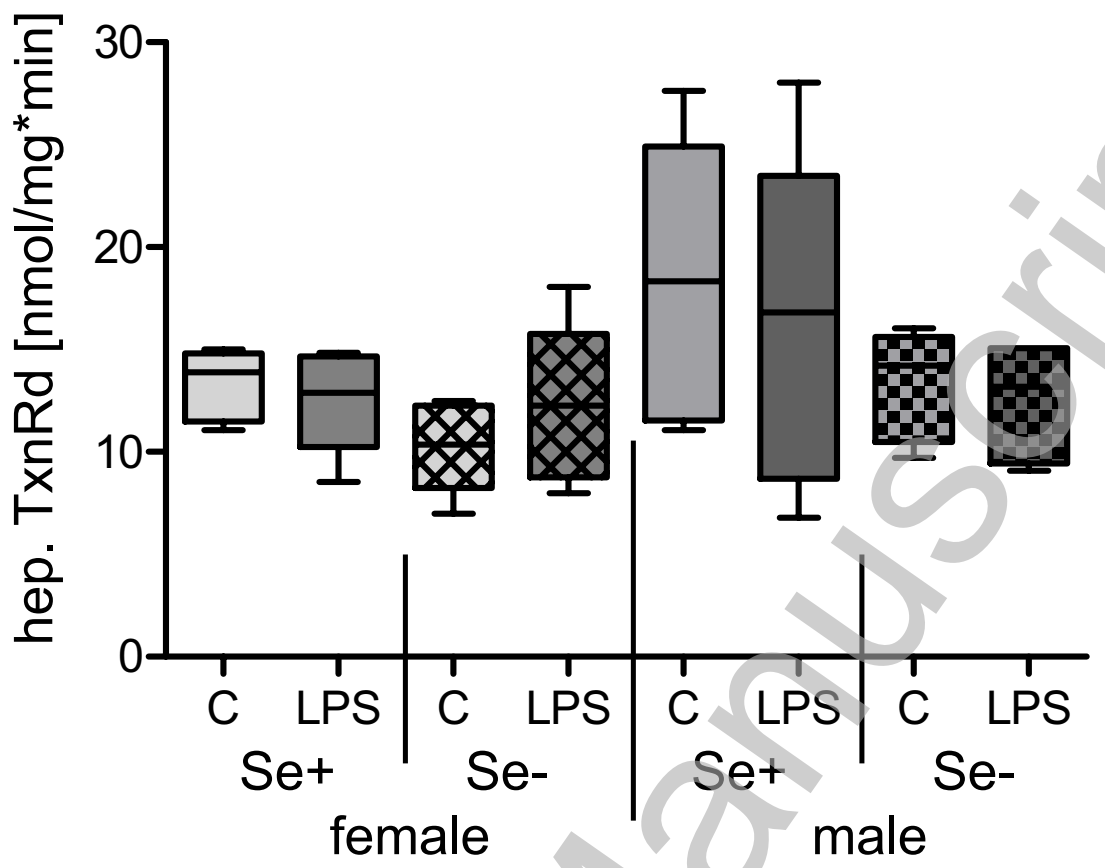

Fig. 4F

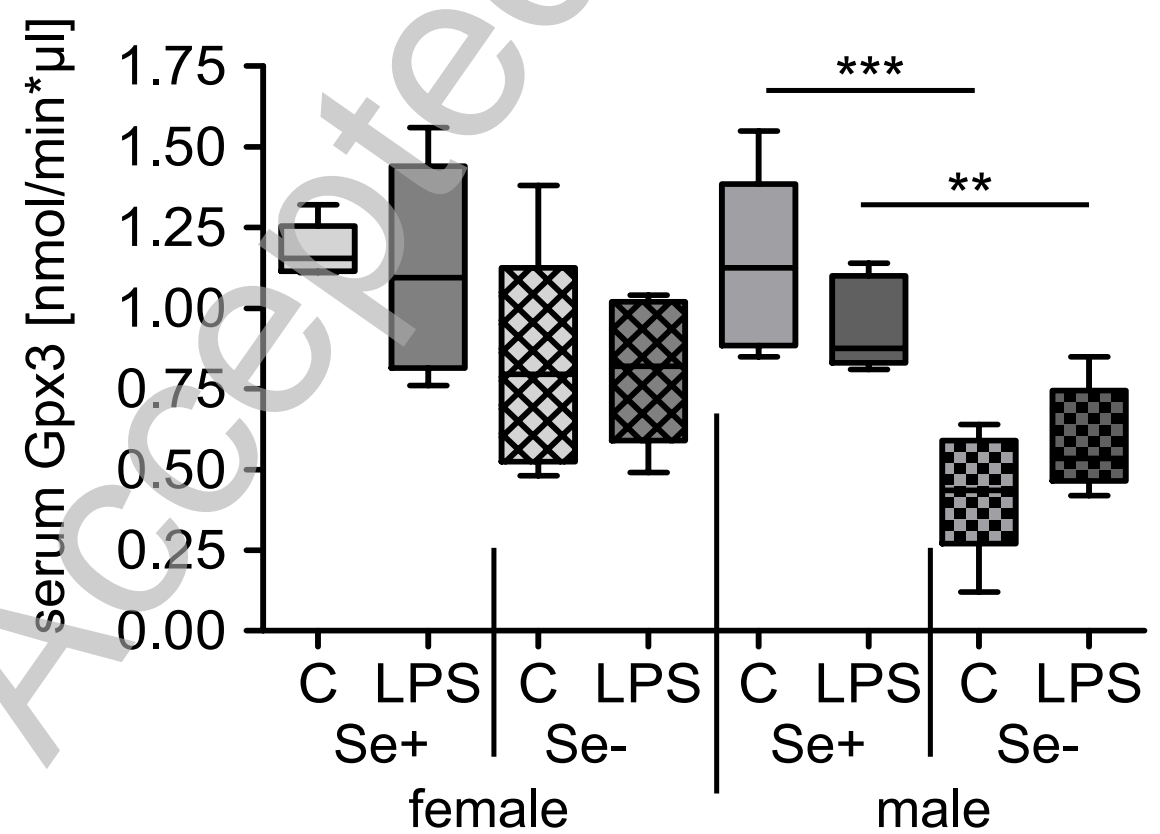


Fig. 5
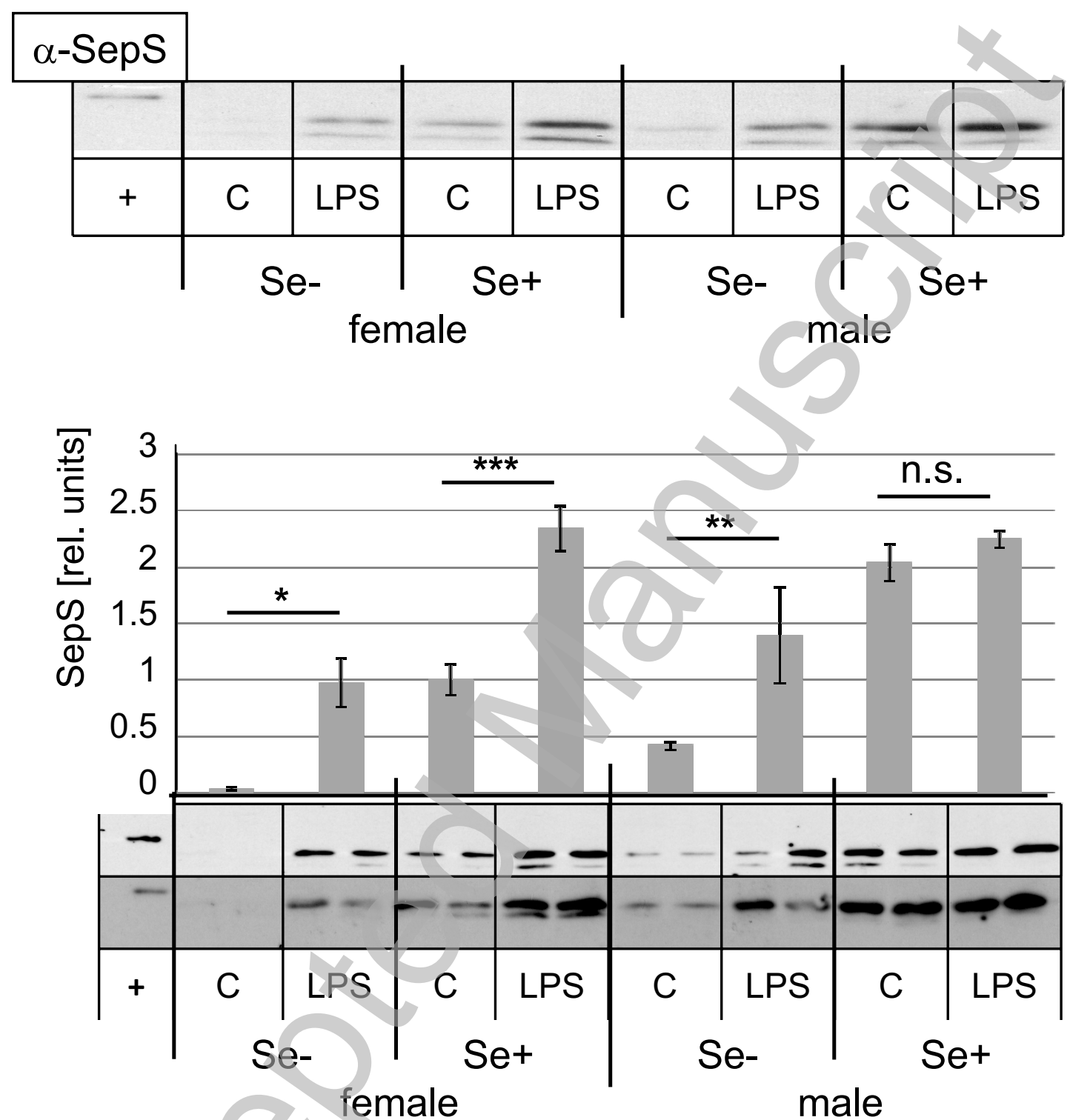